\title{
MJN THE CORRELATION BETWEEN NURSE TIME RESPONSE AND THE HEMODINAMIC STATUS TO THE HEAD INJURY PATIENT IN IGD ROOM OF RSUD DR. MOEWARDI
}

\author{
Sutiyo Dani Saputro*, Siswanto, Yulian Wiji Utami \\ Nursery Magister Students, Health Faculty, Brawijaya University, Indonesia \\ *Corresponding Author's Email: daniyoyo92@gmail.com
}

\begin{abstract}
Background: Head injury is the accidence that cause disability even death. The head injury prevalence always increase so it need the proper and accurate handling is ussualy called by response time. The cancelled handling cause the worse hemodinamic status to the head injury patient. Objective: This objective of the research is to know the correlation nurse response time to the hemodinamic status to the head injury patient in the IGD room of RSUD Dr. Moewardi. Methods: The research design is using analitycal observational to this research by using kohort prospective approach. The research was held in IGD room RSUD Dr. Moewardi during 17th of February-25th of March 2020. The research population is all head injury patient in IGD. The sampling technique isusing the sum of sampling with the sample total 105 patient. The research instrument use responce time observation paper and the hemodinamic status (Modified aldrete score). Univariat analysis use frequency and distribution. Bivariat analysis use the spearman test because the data can not be normaly distributed. Results: Fast Response time can influence the hemodinamic status to the head injury patient by the score is $p$ value 0,000 . The old respose time make the head injury patient condition getting worse becuse the worse of blood circulation in the brain or the bleeding in the brain. The worsen of blood circultion will influence the brain function so the hemodinamic is decese. Conclusion: There is a correlation between the nurse response time with the hemodynamic status to the head injury patient in IGD room RSUD Dr. Moewardi.
\end{abstract}

\section{Keyword: Response Time; Hemodynamic Status; Head injury}

\section{INTRODUCTION}

Head injury is the accident that cause the death and disability. Head injury is the main cause in the death and disability cases in the productive age Lumandung, et al., (2014). The head injury cause the edema cerebri because the intracranialbleeding Rahmanti et al., (2016).

The head injury prevalncy always increase it accross 29.770 cases in the world. The head injury cases is traffic accident in the 51 age Gabbe et al.,(2016). The total of head injury getting increase $7.5 \%-8,2 \%$ in 2013 . The head injury that is caused the traffic accident is $40,6 \%$. The head injury in the East Jawa shows the increasing 9,3\%-11,1\% in 2018 Riskesdas et al., (2018).

The head injury is need the right, appropiate and proper handling. Fast handling in the head injury cases in the instalation room become the most important thing. The fast handling in IGD is called respon time
Fadhilah et al., (2015). Response time has the most important role in the saving life to the head injury patien. The handling principle to the head injury patient focuses to the airways control, breathing,circulation, disability and exposure (ABCDE). Respon time to the head injury patient by observe the hemodinamic status, blood sugar observation and saving $\mathrm{PaC} 02$ 35-45 $\mathrm{mmHg}$ Yulius (2010). The right response time is when it on time No. late if the time more than the standart, that is 5 minutes Rembet et al.,(2015).

The head injury patient handling really corelate to the o time and appropiate. The optimal handling in maximum and good outcome is correlate to the platinum ten minutes and golden period. The handlin in the accident place and no longer reference Leksana (2011). The giving handling must by the principle do no futher harm means no giving more head injury Suwaryo et al., (2016). 
The observation of hemodinamic status is very important to the head injury patient of IGD. Hemodinamic status is indicate the patient condition to the head injury patient. Hemodynamic status in the hearth, lung and perifer circulation very important to the head injury patient Lumandung, et al., (2014). The oservation of the awareness level, blood pressure, respiration, oxygen saturation and motoric activity become the scoring source to the hemodynamic status. Scoring source really impacted to the hemodinamyc status changing Kayana et al., (2013).

Head injury patient will get the hemodynamic status. The hemodynamic status can be seen from the blood pressure, pulse fequency, breath frequency, oxygen saturation and the body temperature Rapsang et al., (2015). The distruption of hemodynamic status can influence the aware level. The aware level can be measure by using Gasgow coma scale Kayana et al., (2013). Hemodynamic status can be measured by using modified aldrete score that include the awareness level scoring, phycycal activity, blood pressure, breathing frequency and oxygen saturation Kyker et al., (2013).

Hemodinamic status stabil score if has 8-10 score Kyker et al., (2013). The last research result in RSUD Dr. Moeardi it is gained the head injury data 231 patient COB ( High Head injury), 229 patient of COS (Medium head Injury) and 452 COR (Low Head Injury) in the 1 Januari - 26 November 2019 patient, it means the average of the patient is 82 in a month. (Rekam Medis RSDM, 2019).

The nurse response giving the handling to the patient in RSUD Dr. Moewardi based on the worse patient level by using triase scoring to the patient. In low, medium and high head injury patient has the different respon time. The head injury patient must get the right handling because it will be change the low head injury ecome high head injury if there is undtected early. RSUD Dr. Moewardi is one of the educational hospital the biggest type A state hospital in Surakarta and become the referense hospital in the regency. From thr background so the researcher is interest to held the research by the tittle of "factors that influence the hemodinamyc patient status to the head injury patient in IGD room RSUD Dr. Moewardi”.

\section{METHODOLOGY}

\section{Study design}

This research use observational analytical by using kohert prospective approach

\section{Setting}

This research in the IGD of RSUD dr Mawardi for 17 February-25 march 2020

Participant Selection: Size, Recruitment Procedurs and Characteristics

The research population is all the head injury patient in IGD RSUD. The sampling technique is using total sampling using total sampling by summarizing all the 105 patient. Respondence ctoteria is the patient that able to be respondence, patients is the reference patient from other health facility.

\section{Data Collection}

The research instrument use the observation sheet of respon time and hemodinamyc status (Modified aldrete score). The collecting data is twice when the patient to the hopital and after 6 hours given the handling.

\section{Data Analysis}

Univriat Analysisi use the frequency and distribution. The bivariat analysis use the spearman test because the data undistributed normally.

\section{Ethical Considerations}

The researcher explain the research objective to the corespondent who are ready to participate, the new research earn the reasearch data. This second research has passed ethical clarence in Ethics commision of RSUD Dr. Moewardi by the number is 175/// HREC/ 2020.

\section{RESULTS}

The nursery response time to the head injury patient in IGD room of RSUD Dr. Moewardi.

\section{Table 1: Respon Time Perawat}

\begin{tabular}{|c|c|c|}
\hline Variabel & Mean & SD \\
\hline Respon time & 195.43 & 155.725 \\
\hline
\end{tabular}

The distribution result to the head injury patient is gained mean score is 195.43 second e minutes 15 second) and the deviation standart 155.725

The hemodynamic status to the head injury patient in IGD RSUD Dr. Moewardi.

Table 2: The Hemodynamic Status to the Head Injury Patient

\begin{tabular}{|c|c|c|}
\hline $\begin{array}{c}\text { Status } \\
\text { Hemodinamik }\end{array}$ & Mean & SD \\
\hline Pre & 7.36 & 2.362 \\
\hline Post & 8.30 & 1.793 \\
\hline Selisih & 0.93 & 0.880 \\
\hline
\end{tabular}


Hasil distribusi skor status hemodinamik pada pasien cedera kepala didapatkan hasil pre skor status. The distribution reult of hemodynamic status to the head injury patient is gained the pre score status. The hemodynamic status that is gained in the triage room by the average score is 7.36 and the deviation standard is 2.362. The post score result of hemodynamic is gained after 3 hours given the handling by the average score is 8.30 and the deviation standart is 1.793 . The distribution difference of hemodynamic status shows the minimum score is 0 , the maximum score is 3 the average is 0.93 and the deviation standard is 0.880 .

The correlation of nursery response time with the hemodynamic status to the head injury patient in the IGD room of RSUD Dr. Moewardi.

Table 3: Data Normality Test

\begin{tabular}{|l|c|}
\hline Variabel & P value \\
\hline Status hemodinamik & 0.000 \\
\hline Respon time & 0.000 \\
\hline
\end{tabular}

The result of normality test use kolmogorov smimov show the $p$ result in the hemodynamic status 0.000 and the respon time 0.000 so the $p$ value $<0.05$ so the data is undistributed normaly.

Table 4. The Correlation Between the Nurse Response time with the Hemodynamic Status

\begin{tabular}{|c|c|c|}
\hline \multicolumn{1}{|c|}{ Variabel } & $\boldsymbol{r}$ & $\boldsymbol{p}$ \\
\hline $\begin{array}{l}\text { Respon time -status } \\
\text { hemodynamic }\end{array}$ & 0.803 & 0.000 \\
\hline
\end{tabular}

The spearman rank test resul shows the $p$ value 0.000 so the $p$ value $<0.05$ so there is correlation nurse respon time to the hemodynamic score status to the head injury patient in IGD RSUD Dr.Moewardi

The nurse response time corelation to the hemodynamic status shows the strong correlation by the opposite direction with the correlation coefficient -0.803 score so it is make therespon time gettting lower so the high score of hemodynamic status.

\section{DISCUSSION}

1. Respon time perawat pada pasien cedera kepala di Ruang IGD RSUD Dr. Moewardi

The distribution result to the nursery response time to the head injury patient is gained the average score 195.43 second ( 3 minutes 15 second) and the deviation standard 155.725 second. The response time frequency is 95 people (90.5\%) and slow is 10 people $(9.5 \%)$ The research result is supported by Surtiningsih, Susilo \& Hamid reseach (2016) that sows the average of response time to the head injury patient is between 2-5 minutes or 120-300 minutes show 4 people (13.3\%) Surtiningsih et al.,(2016).

The fast of response time is the long of time that is neede to give handling to the patient since the patient register to the hospital up to given the handling Surtiningsih et al., (2016). The response time is really influence to the nurse succesful to give the henadling quickly to prevent the disability early. The fast and the appropiateness of response time is really influenced to the each hospital condition that can be seen from the appropiate tools, staff and the nurse skill ingiving appropiate handling Apriani (2017).

2. The hemodynamic status to the head injury patient in the IGD RSUD of Dr. Moewardi.

The distribution of hemodynamic test result to the head injury patient is gained the pre score result of hemodynamic status that is gained in triage room with the average score 7.36 and the deviation staandart is 2.362. The hemodynamic post test result is taken after 3 hours given the handling by the minimum result is 4 , maximum is 10 and the average is 8.30 and the deviation standart is 1.793 . The differet of distribution hemodynamic status shows the minimum score is 0 , maximum sore is 3 , the average is 0.93 and the deviation standart is 0.880 . The research result is supported by Widaryati research (2016) that is shows there is hemodynamic status changing to the head injury patient after given handling the health instalation. The changing of hemodynamic status to the head injury patient is having more blood pressure changing and breath freqency Widaryati (2016).

The hemodynamic status changing to the head injury patient can be influenced by the past in getting the the handling, the worst of head injury is supported by the slow handling that is given can cause the decrease of hemodynamic status score after 3 hours observation.

3. The correlation between time response with the hemodynamic status to the head injury patient in IGD room of RSUD Dr. Moewardi.

The result of spearman rank shows the $\mathrm{p}$ value score 0.000 so the $p$ value $<0.05$ so there is correlation between nursery response time with the hemodynamic status to 
the head injury patient in IGD room of RSUD Dr. Moewardi. The response time correlation eith the hemodynamic score status shows the strong correlation with the different direction with the correlation coefficient -0.803 wo it show the more lower of response time so the more higher of the hemodynamic status. The result research is supported by Haryatun \& Sudaryanto research (2014) that shows the result the fast of response time can related with the succesfullness in giving the head injury patient handling and repair the outcome by the $p$ score value is 0.048 Haryatun et al., (2008).

The Nurse response time is really infleunce in the succesfulness of giving the heand injury patient handling. The fast time in giving the handling is able to minimize the worse of hemodynamic status to the head injury patient Fadhilah et al., (2015). The fast of response time is given the impact and stabilize the hemodynamic status in preventing the complication Nevin et al., (2012).

\section{CONCLUTION AND RECOMMENDATION}

There is correlation between the nurse response time and the hemodynamic status to the hemodynamic status of head injury patient in IGD RSUD Dr.Moewardi with the $p$ value 0.00 . The reseach result is able to be the measurement in doing the response time to the head injury patient in 2-3 minutes.

\section{Conflict of Interests}

The authors declare that they have no conflict of interest

\section{ACKNOWLEDGMENT}

The authors are thankful to the institutional authority for completion of the work.

\section{REFERENCES}

Apriani, A. (2017). Hubungan Kegawat Daruratan dengan Waktu Tanggap pada Pasien Jantung Koroner di RSI Siti Khadijah Palembang. Journal Kesehatan, 8(3), pp 471-477.

Fadhilah, N., Harahap, W.A. \& Lestari, Y. (2015). Faktor-faktor yang Berhubungan dengan Waktu Tanggap pada Pelayanan Kasus Kecelakaan Lalu Lintas di Instalasi Gawat Darurat Rumah Sakit Umum Pusat Dr. M. Djamil Padang Tahun 2013. Journal Kesehatan Andalas, 4(1).

Gabbe, B. J., Lyons, R. A., Simpson, P. M., Rivara, F. P., Ameratunga, S., Polinder, S., Derrett, S. \& Harrison, J.E. (2016). Disability weights based on patient-reported data from a multinational injury cohort. Bulletin of the World Health Organization, 94(11), pp 806-816C.https://doi.org/10.2471/BLT.16.172155.

Haryatun, N. \& Sudaryanto, A. (2008). Perbedaan Waktu Tanggap Tindakan Keperawatan Pasien Cedera Kepala Kategori 1-V Di Instalasi Gawat Darurat Rsud Dr. Moewardi. Journal Berita Ilmu Keperawatan, 1(2), pp 69-74.

Kayana, I.B.A., Maliawan, S. \& Kawiyana, I.K.S. (2013). Intracranial pressure monitoring technique. E-Journal Medika Udayana, pp 480-501.

Kyker, M. \& Burke, B. (2013). Speeds criteria vs. modified aldrete and fast-track criteria for evaluating recovery in outpatients. Open Journal of Anesthesiology, 3(07), pp 309.

Leksana, E. (2011). Pengelolaan Hemodinamik. Dalam Journal CDK, (38).

Lumandung, F.T., Siwu, J.F. \& Mallo, J.F. (2014). Gambaran Korban Meninggal Dengan Cedera Kepala Pada Kecelakaan Lalu Lintas Di Bagian Forensik Blu Rsup Prof. Dr. Rd Kandou Manado Periode Tahun 2011-2012.eCliniC, 2(1).

Nevin, D.G., Perkins, Z. \& Lockey, D.L. (2012). The relationship between head injury and the haemodynamic response to tracheal intubation. Scandinavian Journal of Trauma, Resuscitation and Emergency Medicine, 20(1), pp 1-1.

Rahmanti, A. \& Putri, D.K. (2016). Mobilisasi Progresif terhadap Perubahan Tekanan Darah Pasien di Intensive Care Unit(ICU). Journal Ilmiah Kesehatan Keperawatan, 12(1).

Rapsang, A.G. \& Shyam, D.C. (2015). Scoring systems of severity in patients with multiple trauma. Cirugía Española (English Edition), 93(4), pp 213-221. 
Rembet, M.A., Mulyadi, N. \& Malara, R. (2015). Hubungan Response TIME Perawat Dengan Tingkat Kepercayaan Keluarga Pasien Pada Triase Kuning (Urgent) Di Instalasi Gawat Darurat RSU Gmim Kalooran Amurang. Journal Keperawatan, 3(2).

Riskesdas. (2018). Riset Kesehatan Dasar. Badan Penelitian dan Pengembangan Kesehatan Kementerian Kesehatan RI.

Surtiningsih, D., Susilo, C. \& Hamid, M. A. (2016). Penerapan Response Time Perawat Dalam Pelaksanaan Penentuan Prioritas Penanganan Kegawatdaruratan Pada Pasien Kecelakaan Di IGD RSD Balung. The Indonesian Journal of Health Science, 6(2).

Suwaryo, P.A.W., Wihastuti, T.A. \& Fathoni, M. (2016). Analisis faktor-faktor yang berhubungan dengan outcome pasien cedera kepala di IGD RSUD Prof. Dr. Margono Soekardjo Purwokerto. Journal Ilmiah Kesehatan Keperawatan, 12(3).

Widaryati, W. (2016). Pengaruh terapi murotal Al Qur'an terhadap hemodinamik dan GCS pasien cedera kepala. Journal Kebidanan dan Keperawatan, 12(1), pp 78-83.

Yulius, T. (2010). Acid-base disorder due to hypernatremia in head injury. Journal of Anastesia and Critical Care, 28(3), pp 34-44. 